\title{
Makna Kontekstual Meme Humor Pada Media Sosial Instagram dalam Fanspage Meme Comic Indonesia (MCI) Edisi Januari-Februari
}

(KAJIAN SEMANTIK)

Oleh:

Farah Adiba

\begin{abstract}
ABSTRAK
Bahasa memiliki fungsi sebagai alat komunikasi yang baik agar tercapai maksud dan tujuan yang diinginkan. Penelitian ini bertujuan untuk menganalisis makna kontekstual. Konteks situasi yang meliputi. 1) medan wacana 2) pelibat wacana serta 3) sarana wacana yang terdapat pada Meme Humor. Khususnya, dalam fanspage Meme Comic Indonesia. Pendekatan penelitian ini adalah kualitatif dengan metode deskriptif. Data dalam penelitian ini berupa teks dan gambar, sumber data dalam penelitian ini media sosial yang berbentuk aplikasi yaitu Instagram. Khsususnya, fanspage Meme Comic Indonesia. Teknik pengumpulan data dilakukan dengan metode dokumentasi dan teknik catat. Hasil analisis penelitian konteks situasi yang pertama. Yakni medan wacana unsur aktivitas sosial dan latar, baik latar tempat, waktu, dan suasana. Aktivitas yang merujuk pada sesuatu yang sedang terjadi, hal ini ditemukan adanya tiga puluh lima Meme yang memiliki unsur aktivitas sosial. Latar merujuk pada tempat terjadinya, baik latar tempat, waktu, dan suasana. Hal ini ditemukan tiga puluh empat Meme. Tataran konteks situasi yang kedua. Yakni pelibat wacana yang mencakup peran sosial, status sosial, dan jarak sosial. Hal ini seluruh Meme yang dianalisis memiliki unsur pelibat wacana. Tataran konteks situasi terakhir yakni sarana wacana yang mencakup unsure peran bahasa, tipe interaksi, medium, saluran, dan modus retoris. Seluruh Meme yangdianalisis memiliki unsur sarana wacana.
\end{abstract}

\section{Kata Kunci: Konteks Situasi, Meme Comic Indonesia}

\section{PENDAHULUAN}

Bahasa merupakan sistem lambang bunyi yang arbitrer yang digunakan oleh anggota suatu masyarakat untuk bekerja sama, berinteraksi, dan mengidentifikasi diri (Kridalaksana, dalam Aminuddin 2003:28). Bahasa merupakan bagian penting dalam kehidupan manusia. Seiring dengan perkembangan zaman, bahasa mampu tumbuh, hidup dan berkembang baik di masyarakat. Penggunaan bahasa yang semakin maju dan berkembang di masa kini menuntut masyarakat untuk mempelajarinya serta memahami makna dan maksud yang terkandung di dalamnya.

Salah satu bentuk teknologi informasi yang mengalami perkembangan signifikan hingga dapat mempengaruhi pola kehidupan dan cara berkomunikasi manusia era global ini adalah teknologi informasi yang dikenal sebagai internet. Internet adalah sebuah jaringan yang dapat menghubungkan beberapa jaringan lokal yang ada pada suatu daerah, kota, bahkan sebuah negara (Nugroho, 2004-03). Internet memberikan akses untuk berkomunikasi dan berbagi informasi dengan mudah, sehingga ikut mengubah pola komunikasi manusia. Dengan menggunakan beberapa produk dari internet tersebut dapat mempermudah manusia dalam berkomunikasi secara tidak langsung, sehingga munculah sebuah media baru agar dapat mempermudah dalam berkomunikasi.

Media baru dapat dibatasi sebagai ide, perasaan, dan pengalaman yang diperoleh seseorang melalui medium (media) dan cara berkomunikasi yang baru, berbeda dan lebih menantang (Peter Ride \& Andrew Dewdney, 2006:4). Media sosial adalah sebuah media online, yang para penggunanya bisa dengan mudah berpartisipasi, berbagi dan menciptakan isi, meliputi blog, jejaring sosial, wiki, dan dunia virtual (Juju dan 
Suliantana, 2010-07). Misalnya proses komunikasi yang semakin beragam, melalui Facebook, Twitter, Instagram, Line, Path, dan lain-lainnya. Semakin beragamnya media sosial, maka semakin beragamnya yang dihasilkan dari media sosial tersebut. Seperti banyaknya akun-akun atau fanspage yang berisi quotes keagamaan, cinta, sindiran, bahkan munculnya gambar-gambar yang sifatnya menghibur.

Akhir-akhir ini geliat permainanpermainan visual yang menjadi konsumsi masyarakat virtual hari ini terjadi secara masif. Berbagai visualisasi gambar setiap hari hadir di berbagai media sosial, seperti Facebook, Twitter, Instagram, Path, Line, dan lain-lain. Berbagai modifikasi dari citra-citra fotografis mengantarkan teks yang memiliki maksud beragam dengan gaya ejekan atau sindiran serta kritik menggilitik. Pesan dari teks yang disampaikan diangkat dari keseharian kehidupan masyarakat. Seperti pengalaman hidup, agama, cinta dan lain-lain. Pesan yang diangkat lebih sering menjadi representasi dari hal-hal yang menjadi populer atau sedang diperbincangkan oleh masyarakat kekinian.

Meme adalah sebuah gambar, video, kata, atau yang lainnya, yang bersifat lucu kemudian disalin dan disebarkan secara luas oleh pengguna internet, yang sering kali melakukan variasi kecil terhadap apa yang sudah ada. Indonesia keberadaan Meme telah menjadi keseharian para pengguna media social dalam mengekspresikan suatu hal. Meme yang bervariasi itu bersumber bisa dari akun media sosial maupun fanspage. Indonesia sendiri Meme dengan berbagai tema dan cukup banyak disukai dan diikuti olch banyak pengguna media sosial adalah Meme Comic Indonesia (MCI) dan Meme \& Rage Comic Indonesia (MRCI).

Penelitian Meme ini menggunakan kajian tentang semantik. Khususnya, makna kontekstual. Semantik adalah satu studi dan analisis tentang makna-makna linguistik (Parera, 2004:42). Sedangkan, makna menurut Kamus Besar Bahasa Indonesia (KBBI) berarti maksud pembicara atau penulis, pengertian yang diberikan pada suatu kebahasaan. Chaer (1994:289-296) berpendapat bahwa jenis- jenis makna terbagi menjadi beberapa jenis, yaitu: makna leksikal, makna gramatikal, makna kontekstual, makna referensial, makna nonreferensial, makna denotatif, makna konotatif, makna konseptual, makna asosiatif, makna kata, makna istilah, makna idiom, dan makna peribahasa.

Peneliti menggunakan analisis makna kontekstual. Khususnya, konteks situasi yang dipaparkan oleh IIalliday. Makna kontekstua! adalah makna sebuah leksem atau kata yang berada dalam konteks (Chaer, 1994:290). Konteks juga dapat berkenaan dengan situasinya yakni tempat, waktu, dan lingkungan penggunaan leksem tersebut. Teori ini membahas tentang konteks situasi dalam suatu pemakaian bahasa. Dalam konteks situasi memiliki tiga unsur yaitu, medan wacana, pelibat wacana dan sarana wacana.

Peneliti mengumpulkan 67 data dari fanspage Meme Comic Indonesia (MCI). Data tersebut dikumpulkan dalam jangka waktu Januari sampai Februari. Pada bulan Januari dan Februari banyak Meme yang membahas tentang harapan pada bergantinya tahun, fakta-fakta yang dialami setiap orang yang mengalami percintaan, sampai putusnya hubungan pacaran siswa SMP atau SMA yang akan menghadapi Ujian Nasional, serta realitas sosial lainnya. Meme yang dikumpulkan peneliti yakni bersifat mengkritik, menyindir, sesuai dengan realitis sosial, namun tetap dalam hal ini Meme tetap menghibur. Namun, peneliti hanya memilih Meme-Meme yang mendominasi munculnya medan wacana, pelibat wacana, serta sarana wacana.

Berdasarkan pemaparan sebelumnya, maka media sosial yang digunakan dalam penelitian ini adalah Instagram. Instagram merupakan aplikasi media sosial yang dapat mengunggah foto dan video ke halaman utama Instagram. Ada beberapa hal alasan peneliti menggunakan media Instagram ini, yang pertama, Instagram dapat dengan mudah di unduh dan di pasangakan ke smartphone, yang kedua, pengguna Instagram sangat mudah menemukan fanspage yang berisi Meme salah satunya adalah Meme Comic Indonesia (MCI) sesuai dengan fokus objek penelitiannya. 
Mengacu pada penjelasan di atas, bahwa peneliti memilih Meme humor untuk di analisis dengan menggunakan kajian makna kontekstual. Khususnya, konteks situasi yang dikemukakan oleh Halliday. Latar belakang inilah peneliti mencoba untuk meneliti medan wacana, pelibat dan sarana wacana yang terdapat dalam Meme humor dalam fanspage Meme Comic Indonesia (MCI). Maka peneliti tertarik menelitinya dengan judul "Makna Kontekstual Meme Humor Pada Media Sosial Instagram Dalam Fanspage Meme Comic Indonesia (MCI)".

\section{RUMUSAN MASALAH}

1.2.1 Bagaimana medan wacana Meme Humor pada media sosial Instagram dalam fanspage Meme Comic Indonesia (MCI)?

\subsubsection{Bagaimana pelibat wacana dalam Meme humor pada media social Instagram dalam fanspage Meme Comic Indonesia (MCI)?}

1.2.3 Bagaimana sarana wacana Meme humor pada media sosial Instagram dalam fanspage Meme Comic Indonesia (MCI)?

\section{PENDEKATAN PENELITIAN}

Penelitian ini merupakan penelitian deskriptif-kualitatif. Menurut Ibrahim (2015:52) pendekatan penelitian kualitatif adalah cara kerja penelitian yang menekankan pada aspek pendalaman data demi mendapatkan kualitas dari hasil penelitian. Olch karena itu, pendekatan kualitatif lebih pada menguraikan dengan deskriptif kata, atau kalimat, disusun secara berurutan dari mengumpulkan data hingga menafsirkan dan melaporkan hasil penelitian. Dalam penelitian kualitatif peneliti memerlukan metode untuk mendapatkan data secara mendalam.

Menurut Sudaryanto (1993:62), metode deskriptif adalah metode penelitian yang dilakukan semata-mata berdasarkan fakta kebahasaan yang ada atau fenomena yang secara empiris hidup pada penutumya. Tujuan metode deskriptif ini adalah untuk membuat gambaran atau lukisan yang secara sistematis, faktual, dan akurat mengenai fakta-fakta, sifat, serta hubungan antar sesama fenomena yang diselidiki. Dalam penelitian ini pendekatan deskriptif memang sangat diperlukan untuk memperoleh datadata yang akurat.

\section{HASIL DAN PEMBAHASAN}

Makna kontekstual sendiri berarti kontekstual adalah makna kata yang sesuai dengan konteksnya, karena dari beberapa uraian diatas dari makna kontekstual dapat diartikan sebagai makna kata atau leksem yang berada pada suatu uraian atau kalimat yang dipengaruhi oleh situasi, tempat, waktu, dan lingkungan penggunaan kata tersebut. Artinya, munculnya makna kontekstual bisa disebabkan oleh situasi, tempat, waktu, dan lingkungan. Menurut Halliday, seperti yang telah disinggung sebelumnya, makna kontekstual terbagi atas tiga bagian yaitu medan wacana, pelibat wacana dan sarana wacana.

Medan wacana merujuk kepada aktivitas sosial yang sedang terjadi serta latar institusi tempat satuan-satuan bahasa itu muncul (Halliday, 1992:33). Pelibat wacana merujuk pada hakikat relasi antarpartisipan, termasuk pemahaman peran dan statusnya dalam konteks sosial dan lingual. Untuk menganalisis pelibat, yang mencakup tiga hal, yakni peran agen atau masyarakat, stacus sosial dan jarak sosial. Pelibat wacana merujuk pada hakikat relasi antarpartisipan, termasuk pemahaman peran dan statusnya dalam konteks sosial dan lingual. Untuk menganalisis pelibat, yang mencakup tiga hal, yakni peran agen atau masyarakat, status sosial dan jarak sosial. Sarana wacana merujuk pada bagian bahasa yang sedang dimainkan dalam situasi, termasuk saluran yang dipilih, apakah lisan atau tulisan. Untuk menganalisis sarana wacana mencakup lima hal, yakni peran bahasa, tipe interaksi, medium, saluran, dan modus retoris.

Dibawah ini akan dibahas makna kontekstual yang ditemukan pada Meme humor pada media sosial Instagram dalam fanspage Meme Comic Indonesia (MCI).

(1) Sumber data: www.instagram.com/memecomicError! Hyperlink reference not valid.

Kode data: $\mathrm{MHO1}$ 


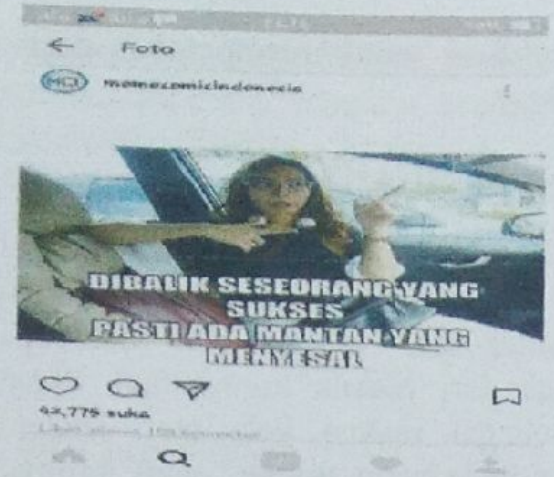

\section{Gambar 4.1 (mantan vs kesuksesan)}

Medan wacana dari data tersebut memiliki aktivitas sosial dan latar tempat. Aktivitas sosial merujuk pada sesuatu yang sedang terjadi, hal ini terlihat seorang perempuan sedang duduk didalam mobil dengan ekspresi yang menampilkan ekspresi sindiran. Aktivitas tersebut dibuktikan dengan sikap yang dilakukan individu dengan menunjuk sesuatu dengan tangannya scrta ekspresi yang ditampilkan. Latar tempat data diatas menunjukan Meme tersebut terjadi di dalam mobil.

Data nomer (1) memiliki unsur pelibat wacana yakni unsur peran sosial, status sosial serta jarak sosial. Peran sosial menunjukan peran individu sebagai perempuan, hal ini terlihat dari aktivitas yang dilakukan dalam Meme yakni seorang perempuan yang sedang menyindir para mantan. Status sosial yang ditampilkan memiliki status sejajar, hal ini terkait status individu dalam Meme sebagai perempuan. Dikatakan sejajar karena perempuan dalam hal ini disebut sebagai mantan. Jarak sosial menampilkan tidak adanya keakraban, hal ini dibuktikan dengan individu dalam Meme yang menyindir individu lain.

Sarana wacana pada Meme diatas mencakup peran bahasa, tipe interaksi, medium, saluran, dan modus retoris. Peran bahasa sebagai penyokong/tambahan. $\mathrm{Hal}$ ini dikatakan tambahan karena bahasa membantu aktivitas yang terdapat dalam Meme. Tipe interaksi merujuk pada jumlah pelaku dalam Meme yakni monologis. Hal ini dibuktikan dengan individu dalam Meme terdapat satu orang, yakni seorang perempuan. Medium merujuk pada sarana yang digunakan yakni tulisan dan isyarat, sesuai dengan pengaplikasian dari saluran grafis dan saluran visual. Terlihat saluran grafis pengaplikasian dari tulisan yakni "dibalik sesorang yang sukses pasti ada mantan vang menyesal", sedangkan terlihat saluran visual pengaplikasian dari isyarat yakni ekspresi yang ditampilkan dalam Meme. Modus retoris pada Meme diatas adalah sindiran. Disebut sindirian karena dalam Meme ditampilkan ekspresi yang menunjukan ketidaksukaan dan didukung dengan maksud dari tulisan yang terdapat dalam Meme,

\begin{tabular}{|l|l|l|}
\hline Medan wacana & Pelibat wacana & Sarana wacana \\
\hline $\begin{array}{l}\text { Terdapat } \\
\text { adanya } \\
\text { medan situasi } \\
\text { baik dari } \\
\text { aktivitas } \\
\text { sosial serta } \\
\text { latar tempat }\end{array}$ & $\begin{array}{l}\text { Terdapar } \\
\text { adanya peran } \\
\text { individu } \\
\text { dengan }\end{array}$ & $\begin{array}{l}\text { Sarana yang } \\
\text { ditampilkan } \\
\text { mencakup } \\
\text { kelima aspek } \\
\text { baik peran } \\
\text { bahasa, tipe } \\
\text { interaksi, } \\
\text { jarak sosial }\end{array}$ \\
& & $\begin{array}{l}\text { medium, } \\
\text { saluran, dan } \\
\text { modus } \\
\text { retoris }\end{array}$ \\
\hline
\end{tabular}

(2)

Sumber

data:

www.instagram.comimemecomic Error!

Hyperlink reference not valid.

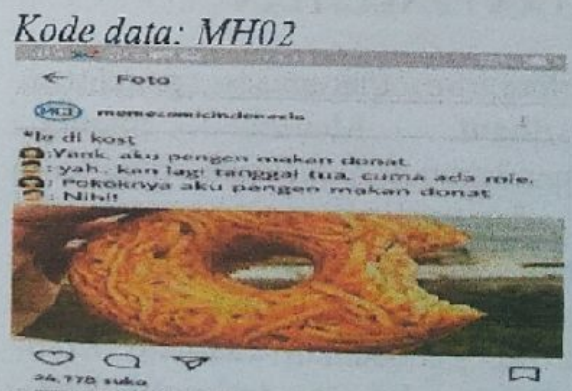

\section{Gambar 8.2 (antara pacar dan tanggal tua)}

Medan wacana merujuk pada aktivitas sosial yang sedang terjadi serta latar tempat. Aktivitas sosial yang ditampilkan yakni sescorang yang meminta donat kepada pasangannya, kemudian diberikan donat yang terbuat dari mie goreng. Seseorang yang meminta donat, dibuktikan dalam Meme yakni dalam kalimat "yank... aku pengen makan donat" serta "pokoknya aku pengen makan donat". Dan diberikan donat yang terbuat dari mic goreng ini dibuktikan dalam Meme yakni pada kata "Nih... (menunjukan gambar donat terbuat dari mie)". Latar tempat yang ditampilkan yakni di kos-kosan, hal ini 
terbukti terdapat keterangan pada awal kalimat dalam Meme yakni "/e di kost

Pelibat wacana dari data diatas memiliki peran sosial, status dan jarak sosial Peran sosial ditampilkan oleh peran individu sebagai pasangan pacar. Dikatakan sepasang pacar, terbukti dari kata sapaan yang dilakukan salah satu individu yakni kata "yank..". Kemudian permintaan yang dilakukan oleh salah satu individu dalam Meme, permintaan tersebut dilakukan dengan paksaan, terbukti dalam kalimat "pokoknya aku pengen makan donai". Terkait dengan status sosial memiliki status sejajar, dikatakan sejajar karena aktivitas yang dilakukan antar individu tersebut merupakan aktivitas yang wajar terjadi terhadap pasangan yang memiliki pacar. Jarak sosial menunjukan adanya keakraban, hal ini terbukti dengan percakapan yang dilakukan antar individu yang terjalin sangat dekat dan akrab.

Peran bahasa yang ditampilkan dalam Meme menunjukan peran tambahan. Hal ini dikarenakan bahasa membantu aktivitas yang terdapat dalam Meme. Terbukti dengan kata "Nih!!" yang merujuk pada gambar donat yang terbuat dari mie. Tipe interaksi yang ditampilkan dalam Meme yakni terdapat dua pelaku, maka dialogis. Hal ini terbukti adanya dua individu dalam Meme sekaligus adanya percakapan antar keduanya. Medium yang digunakan dalam Meme yakni tulisan dan isyarat, sesuai dengan saluran grafis dan visual. Terlihat saluran grafis pengaplikasian dari medium tulisan yakni " $/ e$ di kost..dsf', sedangkan saluran visual pengaplikasian isyarat terlihat dari gambar donat yang ditampilkan dalam Meme. Modus retoris dalam Meme termasuk dalam permintaan. Hal ini dibuktikan dengan kalimat permintaan yang dituturkan oleh salah satu individu dalam Meme yakni "yank, aku pengen makan donat".

\begin{tabular}{|c|l|l|}
\hline $\begin{array}{l}\text { Medan } \\
\text { wacana }\end{array}$ & $\begin{array}{l}\text { Pelibat } \\
\text { wacana }\end{array}$ & $\begin{array}{l}\text { Sarana } \\
\text { wacana }\end{array}$ \\
\hline $\begin{array}{l}\text { Adanya } \\
\text { medan } \\
\text { situasi }\end{array}$ & $\begin{array}{l}\text { Terdapat } \\
\text { adanya peran } \\
\text { individu } \\
\text { baik dari } \\
\text { aktivitas } \\
\text { sosial serta }\end{array}$ & $\begin{array}{l}\text { Sarana } \\
\text { yang } \\
\text { ditampilkan }\end{array}$ \\
status, dan & $\begin{array}{l}\text { mencakup } \\
\text { kelima } \\
\text { aspek baik }\end{array}$ \\
\hline
\end{tabular}

\begin{tabular}{|l|l|l|}
\hline latar tempat & jarak sosial & $\begin{array}{l}\text { peran } \\
\text { bahasa, tipe } \\
\text { interaksi, } \\
\text { medium, } \\
\text { saluran, dan } \\
\text { modus } \\
\text { retoris }\end{array}$ \\
\hline
\end{tabular}

(3)

\section{Sumber}

data:

www. instagram comimemecomic Error!

Hyperlink reference not valid.

\section{Kode daia: $\mathrm{MHO} 3$}

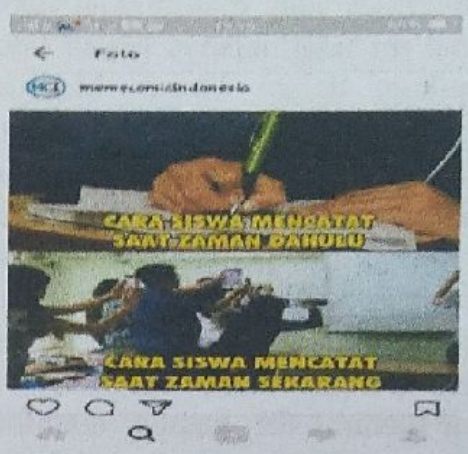

Gambar 4.3 (murid jaman dulu dan sekarang)

Medan wacana dari data $\mathrm{MHO} 3$ memiliki aktivitas sosial dan lata tempat. Aktivitas sosial menampilkan kegiatan siswa/mahasiswa yakni mencatat. Namun, dalam hal ini memiliki perbedaan yakni menulis dan memfoto. Terbukti menulis dapat dilihat dari gambar sisi atas, serta terbukti memfoto dapat dilihat dari gambar yang terdapai di sisi bawah. Latar tempat yang ditampilkan yakni terjadi di sebuah ruang kelas, hal ini terlihat dari perlengkapan kelas seperti meja, dan papan tulis.

Pelibat wacana dari data nomer 3 menampilkan peran, status, dan jarak sosial. Peran sosial menampilkan peran individu sebagai siswa/mahasiswa. Hal ini dibuktikan dengan suasana dalam kelas dengan siswa/mahasiswa didalamnya. Status yang ditampilkan terlihat sejajar dan tidak sejajar. Dikatakan sejajar karena individu dalam Meme berperan sebagai siswa/mahasiswa, dikatakan tidak sejajar karena antar individu memiliki kesibukan masing-masing. Jarak sosial yang ditampilkan menunjukan berjarak, hal ini dibuktikan antar individu tidak ada interaksi. 
Sarana wacana merujuk pada peran bahasa, tipe interaksi, medium, saluran, dan modus retoris. peran bahasa yang ditampilkan dalam Meme termasuk pada peran tambahan. Hal ini karena bahasa membantu aktivitas yang terdapat dalam Meme, yakni pada sisi atas terdapat gambar aktivitas menulis dengan tulisan "cara siswa mencatat saat zaman dahwih", kemudian sisi bawah gambar aktivitas memfoto dengan tulisan "cara siswa mencatat saat zaman sekarang".

Tipe interaksi yang ditampilkan yakni monologis, hal ini tidak adanya lawan tutur yang ditampilkan dalam Meme. Medium yang digunakan pada Meme diatas yakni tulisan dan isyarat, sesuai dengan pengaplikasian saluran grafis dan visual. Terlihat saluran grafis pengaplikasian dari medium tulisan yakni "cara siswa mencatat saat zaman damulu..dst", sedangkan saluran visual pengaplikasian media isyarat yakni gambar menulis dan gambar memfoto dalam Meme. Modus retoris yang ditampilkan dalam Meme merujuk pada sebuah fakta, dikatakan fakta dibuktikan dengan realitas yang terjadi di dalam dunia pendidikan dengan kecanggihan teknologi, hal ini yang membuat siswa jaman sekarang lebih memilih jalan pintas untuk mencalat pelajaran.

\begin{tabular}{|l|l|l|}
\begin{tabular}{|l|l|} 
Medan \\
wacana
\end{tabular} & $\begin{array}{l}\text { Pelibat } \\
\text { wacana }\end{array}$ & $\begin{array}{l}\text { Sarana } \\
\text { wacana }\end{array}$ \\
\hline $\begin{array}{l}\text { Adanya } \\
\text { situasi baik } \\
\text { dari aktivitas } \\
\text { sosial serta } \\
\text { latar tempat }\end{array}$ & $\begin{array}{l}\text { Terdapat } \\
\text { adanya peran } \\
\text { individn } \\
\text { dengan status, } \\
\text { dan jarak sosial }\end{array}$ & $\begin{array}{l}\text { Mencakup } \\
\text { lima } \\
\text { unsurc } \\
\text { sarana } \\
\text { wacana } \\
\text { yakni pcran } \\
\text { bahasa, tipe } \\
\text { interaksi, } \\
\text { medium, } \\
\text { saluran, } \\
\text { serta modns } \\
\text { retoris }\end{array}$ \\
\hline (4) & Sumber & \\
\hline
\end{tabular}

www. instagram com memecomikError!

Hyperlink reference not valid.

Kode data:MHO4

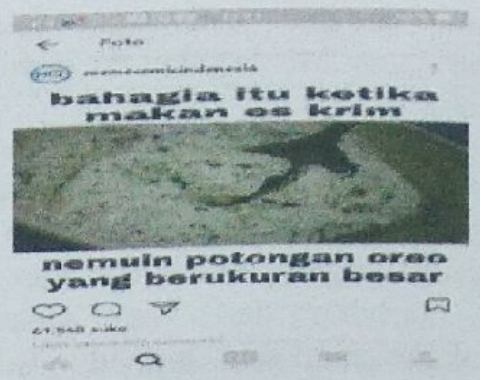

\section{Gambar 4.4 (penikmat ice cream)}

Medan wacana dari data MH04 hanya aktivitas sosial yakni sedang makan ice cream. $\mathrm{Hal}$ ini terlihat dari gambar ice cream yang terdapat dalam Meme serta kalimat yang menunjukan bahwa sedang makan yakni "ketika makan es krim". Latar suasana yang ditampilkan yakni bahagia, hal ini terbukti pada kalimat "bahagia itu ketika makan es krim"

Pelibat wacana yang ditampilkan yakni peran sosial, hal ini individu berperan sebagai penikmat ice cream. Terkait dengan tempat individu dalam Meme memiliki status sejajar, hal ini dikatakan sejajar karena setiap individu menyukai ice cream. Jarak yang ditampilkan yakni tidak memiliki jarak/akrab, hal ini terlihat dari setiap individu menikmati ice cream dengan sesama teman atau menikmatinya dengan sendirian.

Sarana wacana yang dimiliki Meme diatas yakni peran bahasa, tipe interaksi, medium dan saluran. Peran bahasa yang ditampilkan dalam Meme diatas termasuk pada peran tambahan. Hal ini karena bahasa membantu aktivitas lain dalam Meme, yakni pada bahasa sebagai tulisan Meme "bahagia itu ketika makan es krim nemuin potongan oreo yang berukuran besar", sedangkan aktivitas lain. yakni dengan gambar sendok dan ice cream. Tipe interaksi yang ditampilkan menunjukan monologis, hal ini terlihat tidak adanya pelaku lain yang ditampilkan dalam Meme.

Medium dalam Meme menunjukan tulisan dan isyarat, sesuai dengan pengaplikasian saluran grafis dan visual. Terlihat saluran grafis pengaplikasian dari medium tulisan yakni "bahagia itu ketika makan es krim nemuin potongan oreo yang berukuran besar", sedangkan saluran visual pengaplikasian media isyarat yakni gambar 
ice cream oreo. Modus retoris merujuk pada perasaan teks secara keselurahan yakni menunjukan fakta. Dikatakan fakta, dibuktikan dengan perasaan bahagia penikmat ice cream apabila menemukan potongan oreo didalam ice cream yang dimakan.

\begin{tabular}{|l|l|l|}
\hline $\begin{array}{l}\text { Medan } \\
\text { wacana }\end{array}$ & $\begin{array}{l}\text { Pelibat } \\
\text { wacana }\end{array}$ & Sarana wacana \\
\hline $\begin{array}{l}\text { Ditemukan } \\
\text { aktivitas }\end{array}$ & $\begin{array}{l}\text { Memiliki } \\
\text { unsur-unsur }\end{array}$ & $\begin{array}{l}\text { Sarana yang } \\
\text { ditampilkan }\end{array}$ \\
sosial dan & $\begin{array}{l}\text { pelibat wacana } \\
\text { yakni peran } \\
\text { sosial, status } \\
\text { sosial, dan } \\
\text { jarak sosial }\end{array}$ & $\begin{array}{l}\text { mencakup } \\
\text { aspek baik } \\
\text { peran bahasa, } \\
\text { tipe interaksi, } \\
\text { medium, } \\
\text { saluran, dan } \\
\text { modus retoris }\end{array}$ \\
\hline
\end{tabular}

(5)

Sumber

data:

www instagram.com/memecomikError!

\section{Hyperlink reference not valid.}

Kode data: $\mathrm{MH05}$

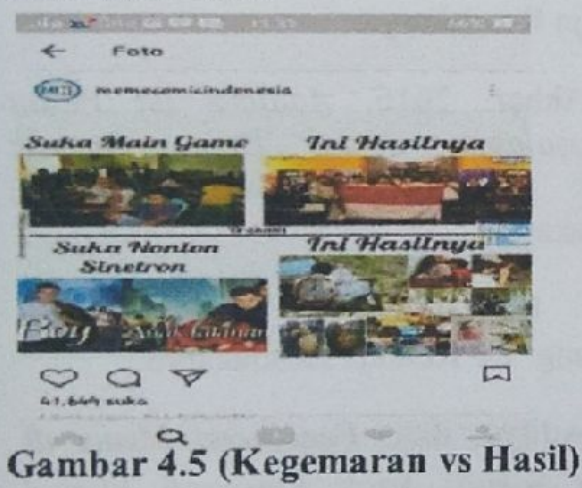

Medan wacana berisi aktivitas sosial serta latar tempat. Meme diatas terdapat empat gambar yang berbeda dengan aktivitas yang berbeda-beda dengan menampilkan anak-anak. Pada gambar pertama menampilkan aktivitas sosial anak-anak yang bermain game di warnet. Pada gambar kedua menampilkan kemenangan yang membawa nama Indonesia. Gambar ketiga menampilkan kesukaan menonton sinetron, dan gambar keempat menampilkan aktivitas anak- anak yang dihasilkan dari menonton sinetron yakni pacar-pacaran. Hal ini terlihat dari masingmasing gambar dalam Meme. Latar tempat yang ditampilkan yakni di warnet, ditempat olimpiade dan tempat-tempat umum, hal ini terbukti dalam masing-masing gambar.
Pelibat wacana menampilkan peran sosial, status, dan jarak sosial. Peran sosial yang ditampilkan didominasi oleh peran individu yakni anak-anak, hal ini dibuktikan dengan anak-anak yang berperan dalam Meme. Status yang ditampilkan menunjukan kategori sejajar dan tidak sejajar, hal ini kategori sejajar karena dalam Meme individu diperankan olch anak-anak, dan kategori tidak sejajar yakni aktivitas yang diperankan antar individu berbeda. Jarak yang ditampilkan memiliki keakraban, hal ini terlihat adanya interaksi antar individu.

Sarana wacana mencakup peran bahasa, tipe interaksi, medium, saluran dan modus retoris. Peran bahasa yang ditampilkan dalam Meme termasuk pada peran tambahan. $\mathrm{Hal}$ ini bahasa membantu aktivitas lain yang terdapat dalam Meme, terbukti dengan bahasa diperankan dengan tulisan "suka main game, ini hasilnya", "suka nonton sinetron, ini hasilnya", sedangkan aktivitas lain ditampilkan dengan masing-masing gambar dalam Mene. Tipe interaksi yang ditampilkan menunjukan monologis, hal ini dibuktikan dengan tidak adanya lawan tutur dalam Meme.

Medium dalam Meme termasuk dalam tulisan dan isyarat, hal ini sesuai dengan pengaplikasian saluran grafis dan visual. Terlihat saluran grafis pengaplikasian dari medium tulisan yakni "suka main game, ini hasilnya", "suka nonton sinetron, ini hasilnya", sedangkan saluran visual pengaplikasian media isyarat yakni terlihat dari gambar-gambar yang ditampilkan dalam Meme. Modus retoris dalam Meme menunjukan fakta. Dikatakan fakta karena mengacu pada realitas sosial yang terjadi pada generasi muda masa kini.

\begin{tabular}{|l|l|l|}
\hline Medan wacana & Pelibat wacana & Sarana wacana \\
\hline $\begin{array}{l}\text { Ditemukan } \\
\text { aktivitas }\end{array}$ & $\begin{array}{l}\text { Terdapat } \\
\text { unsur-unsur }\end{array}$ & $\begin{array}{l}\text { Memiliki } \\
\text { lima unsurr }\end{array}$ \\
$\begin{array}{l}\text { sosial dan } \\
\text { latat tempat } \\
\text { dalam Meme }\end{array}$ & $\begin{array}{l}\text { pelibat yakni } \\
\text { peran sosial, } \\
\text { status, dan jarak } \\
\text { sosial. }\end{array}$ & $\begin{array}{l}\text { sarana wacana } \\
\text { yakni peran } \\
\text { bahasa, tipe } \\
\text { interaksi, } \\
\text { medium, saluran, } \\
\text { dan modus } \\
\text { retoris }\end{array}$ \\
\hline
\end{tabular}

PENUTUP 
Hasil penelitian dan pembahasan dalam bab sebelumnya dapat disimpulkan, Merujuk pada hasil analisis makna kontekstual Meme Humor pada media sosial Instagram dam fanspage Meme Comic Indonesia (MCI) maka diperoleh simpulan. Medan wacana yang memiliki unsur aktivitas sosial dan latar, baik latar tempat, waktu dan suasana. Beberapa Meme dalam fanspage Meme Comic Indonesia, ditemukan 35 Meme yang memiliki unsur aktivitas sosial. Data yang dianalisis tidak semua Meme memiliki unsur latar, ditemukan satu Meme yang tidak memiliki latar yakni MH40. Pelibat wacana yang memiliki unsur peran sosial, status sosial, dan jarak sosial. Dari hasil analisis seluruhnya memiliki unsur-unsur medan wacana. Sarana wacana memiliki lima unsur yakni, 1) peran bahasa 2) tipe interaksi 3) medium 4) saluran 5) modus retoris.

\section{DAFT AR PUSTAKA}

Adi, Nugroho. 2004. Konsep Pengembangan System Basis Data, Informatika. Bandung.

Ayu, I Gusti, dkk. Jenis, Bentuk, dan Fungsi Tindak Tutur Meme Comic Pada Facehook. e-Jurnal Prodi Pendidikan Bahasa dan Sastra Indonesia Undiksha. Vol: 5 No:3. 2016. (di akses 21 April 2017)

Budiargn, Dian. 2015. Berkomunikasi ala Net Generation. Jakarta: PT Elex Media Komputindo Kompas Gramedia.

Chaer, Abdul. 2007. Linguistik Umum. Jakarta: Rineka Cipta.

2005. Pengantar Semantik Bahasa Indonesia. Jakarta: Rineka Cipta,

Daniel H. Purwadi. 1995. Belajar Sendiri Mengenal Internet Jaringan InformasiD nia. Jakarta: Alex Media Komputindo.

Dawkins, Richard. 1976. The Selfish Gene. UK. Oxford University Press. Djajasu arma, Fatimah. 2012 Semantik I Makna Leksikal dan Gramatikal.Bandung: Refika Aditama..
Hasan, Halliday. 1992. Bahasa, Teks dan Konteks. Yogyakarta. Universitas Gadjah Mada.

Humairoh. 2015. Ketepatan Terjemahan Kiab Al-Hikam (Analisis Makna Kontekstual). Skripsi. UIN Syarif Hidayatullah Jakarta.

Kemal, Ishtifa. Makna Kontekstual Bahasa Iklan Rokok Di Televisi. Jurnal Bahasa, Vol. IV Nomer 1 Januari-Juni 2013. (Di akses 11 April 2017)

Mahsun. 2014. Metode Penelitian Bahasa. Bandung Rajawali Pers.

Memecomicindonesia. Tersedia pada ig: memecomicindonesia (MCI). http://mobile.instagram.com/memecomicindo nesiaError! Hyperlínk reference not valid. Februari 2017

Moleong, Lexy J. 2014. Metodologi Penelitian Kualitatif. Bandung. PT Remaja Rosdakarya.

Muslim, Akbar. 2016. Analisis Isi Pesan Permasalahan Sosial Dalam Intenet Meme. Skripsi. UIN Sunan Kalijaga Yogyakarta.

Nasrullah, Rulli. 2015. Media Sosial. Bandung: PT Remaja Rosdakarya.

Nugraha, Aditya, dkk. Fenomena Meme di Media Sosial: Studi Etnografi Virtual Postingan Meme Pada Pengguna Media Sosial Instagram. Jurnal Sosioteknologi, Vol 14-No 3, Desember 2015. Di akses 30 November 2016 nelitian Kuantitatif Kualitatif dan $R \quad \& \quad D$ Bandung: Alfabetha

Pateda, Mansur. Semantik Leksikal. Jakarta: Rineka Cipta, 2010.

Sa'adah. 2011 Analisis Semantik Kontekstual Atas Penerjemahan Kata Arab Serapan (Studi Kasus Kata Fitnah, Hikmah, dan Amanah) Dalam al-Qur'an dan Maknanya Karya M. Quraish Shihab. Skripsi. UIN Syarif Hidayatullah Jakarta. Di akses 30 November 2016 
Salbino, Sherif. 2004. Buku Pintar Gadget Android untuk Pemula: untuk Pemula. Jakarta: Kunci Komunikasi.

Sudaryanto. Metode dan Aneka Teknik Analisis Bahasa. Yogyakarta: Duta Wacana University Press, 1993.
Sugiyono. 2011. Metode Penelitian Kuantitatif Kualitatif dan $R$ \& $D$. Bandung: Alfabeth 